\title{
Article
}

\section{What do parents think about their involvement in speech-language pathology intervention? A Qualitative Critically Appraised Topic}

Skeat, Jemma and Roddam, Hazel

Available at http://clok.uclan.ac.uk/26134/

Skeat, Jemma and Roddam, Hazel ORCID: 0000-0002-0637-1801 (2019) What do parents think about their involvement in speech-language pathology intervention? A Qualitative Critically Appraised Topic. Evidence Based Communication Assessment and Intervention, 13 (1-2). pp. 15-31. ISSN 17489539

It is advisable to refer to the publisher's version if you intend to cite from the work. http://dx.doi.org/10.1080/17489539.2019.1600293

For more information about UCLan's research in this area go to http://www.uclan.ac.uk/researchgroups/ and search for <name of research Group>.

For information about Research generally at UCLan please go to http://www.uclan.ac.uk/research/

All outputs in CLoK are protected by Intellectual Property Rights law, including Copyright law. Copyright, IPR and Moral Rights for the works on this site are retained by the individual authors and/or other copyright owners. Terms and conditions for use of this material are defined in the policies page. 


\section{Critically Appraised Topic (CAT) - Template ${ }^{1}$}

Title: What do parents think about their involvement in speech-language pathology intervention? A Qualitative Critically Appraised Topic.

\section{Authors: Jemma Skeat ${ }^{1}$, Hazel Roddam ${ }^{2}$}

Date: June 2018

Review date: June 2021

Affiliation: 1. Department of Audiology and Speech Pathology, University of Melbourne;

2. School of Health Sciences, University of Central Lancashire

Word Count: 5103

Acknowledgements: With thanks to Tania Celeste, Biosciences Liaison Librarian at the University of Melbourne for her assistance in conducting the search for this paper.

\section{Clinical Bottom Line (APA Level 1):}

Speech-language pathology (SLP) for young children often includes parent or caregiver involvement in therapy, for example in implementing home practice to support skill learning and generalisation. This CAT explored qualitative evidence of the views of parents regarding involvement in intervention for preschool-aged children receiving SLP services. Five appraised qualitative studies of indicative to moderate levels of evidence suggested that parents may expect their involvement to happen in different ways- for example, in decisionmaking, session activities, home practice or simply attendance with their child. Parent expectations are important and need to be clarified to increase the congruence between what is expected and what is experienced, as incongruence may lead to disengagement. Parental involvement may be impacted by a lack of knowledge about how to help their child,

\footnotetext{
${ }^{1}$ Template adapted from Department of Speech Pathology, Flinders University curriculum materials and developed with reference to NSW Speech Pathology EBP Interest Group \& OT CATs, University of Western Sydney.
} 
or because they believe the SLP's direct expertise will be the best help for their child. They may also be held back by practical barriers such as time.

Parental expectations and involvement are flexible and dynamic. Parents anticipate that SLPs will be both experts and teachers, and SLPs can capitalise on this by sharing expertise and knowledge, and teaching parents new skills and approaches, supporting greater involvement. SLPS should also provide explicit opportunities and resources to support parent involvement, and promote ongoing discussion throughout the therapy process, recognising that parents' desire and capacity for involvement may change over time.

\section{Limitations of this CAT (APA Level 1):}

This CAT is potentially limited by the scope of the search, which was determined as part of the CAT methodology. Three relevant databases were searched, one of which (SCOPUS) is a multidisciplinary database which indexes a broad range of journals. Searching was conducted and completed in June, 2018. Papers were limited to English language texts, which may have excluded some relevant studies. All included papers were at an indicative to moderate level of qualitative evidence.

\section{Clinical Scenario/Background (APA Level 1):}

The clinical scenario for this CAT is as follows. A speech-language pathology (SLP) private practice service has a large caseload of preschool children aged 2-5 years with a variety of communication disorders (e.g., speech, language or fluency). The speech-language pathologists (SLPS) in the practice have identified that involvement of caregivers (usually parents) in service provision for preschool-aged children is crucial for successful outcomes (Ebert, 2018; Kummerer \& Lopez-Reyna, 2006). However, there are challenges to engaging caregivers and the team identify that they want to understand how caregivers view their involvement in SLP intervention for young children, and what could be done to support 
increased involvement. For this topic, qualitative research is identified as providing the most appropriate evidence for practice.

\section{Focussed Clinical Question (APA Level 1):}

In line with qualitative synthesis approaches (Cooke, Smith, \& Booth, 2012), a clinical question using a format of PICo (Population, Interest, Context) was formulated (see Table 1): what do caregivers of preschool-aged children with speech, language or communication disorders (2-5 years of age) think of their involvement in speech-language pathology intervention in community-based settings?

Insert table 1 about here

\section{Search Strategy (APA Level 1):}

\section{Databases searched}

A search was conducted with the assistance of a trained librarian researcher. Databases searched were CINAHL (Complete), ERIC and SCOPUS. The latter is a multidisciplinary database which indexes Medline, as well as over 21,000 journals across health, social, physical and life sciences. These databases were chosen as being the most likely to identify relevant qualitative research. Initial search terms used are shown in Table 2.

Insert table 2 about here

\section{Inclusion and Exclusion Criteria (APA Level 1):}

Studies were included if they focused on speech, language, communication or fluency disorders in young children, had a substantial qualitative component addressing parent or caregiver views of their involvement in SLP intervention and were available in English and in full text. Limitations were not set around the date of publication. 
Studies were excluded if they:

- Focused on complex disorders, such as Autism Spectrum Disorder or use of augmentative or alternative communication;

- Explored the views of other parties, such as SLPs or other health care professionals, without including specific qualitative data collection on parent or caregiver views;

- Sought parent/caregiver views of development, disorder, assessment practices, or other related areas, without addressing views of involvement in intervention;

- Addressed SLP intervention in non community-based settings- for example, in hospitals.

\section{Results of the Search (APA Level 1):}

Ten papers were initially identified by review of title and abstract as being potentially relevant for the CAT. Full manuscripts were then scanned to ensure relevance to the clinical question. One paper was excluded at this point (Marshall, Harding, \& Roulstone, 2017) as the parents studied were not necessarily service users, and the focus on views of SLP services (versus child development or other areas discussed in interviews) was limited to one paragraph in the paper.

\section{Evaluation (APA Level 1):}

The remaining nine papers were evaluated using a process developed by the authors of this CAT for initial appraisal of qualitative papers in CATs. This involved 1) using a model developed by Sandelowski and Barroso (2003) to exclude papers unsuitable for qualitative synthesis; 2) applying a hierarchy proposed by Daly et al. (2007) to rank the remaining papers in terms of the strength of qualitative evidence that they present.

Firstly, each paper was classified into one of five categories, focusing on the depth of qualitative analysis presented in the findings: Interpretive explanation, Conceptual/thematic 
description, Thematic survey, Topical survey or No (qualitative) findings. The latter two categories were considered as not meeting minimum requirements for inclusion in the CAT (Sandelowski and Barroso, 2003). Two papers were judged to be topical surveys (Ebert, 2018; Marshall, Goldbart, \& Phillips, 2007); one presented no qualitative findings against this framework (Mathisen et al., 2016). A further study (Kummerer \& Lopez-Reyna, 2006) presented conceptual/thematic description in relation to some of their findings, but presented only a brief discussion of parent views of intervention activities, without evidence of descriptive or conceptual analysis of this component of the study. This was therefore judged to present no qualitative findings of relevance to this CAT. These four papers were excluded, and the five remaining were further reviewed against a qualitative research hierarchy.

Daly et al. (2007) propose a hierarchy of qualitative evidence, ranking studies from Level IV: "limited but insight provoking single-case studies" (p. 44) through to "generalisable studies" (Level I). Like Sandelowski and Barroso (2003), these authors note the strength of qualitative research that provides conceptual and interpretative insights, as compared to descriptive results. However, Daly et al. (2007) also propose features of sampling, data collection, data analysis and the discussion and interpretation of results that strengthen the evidence provided by a study.

Each paper was closely read and compared to the areas provided by Daly et al. (2007) in order to classify the strength of evidence. Table 3 provides a summary of the five papers reviewed and the level of evidence provided. The papers represent indicative to moderate evidence to support practice in this area (Level II-III). The primary difference between studies at level II versus level III was greater conceptual development in relation to analysis, clear and purposive recruitment methods, and use of iterative data collection and analysis.

\section{Insert table 3 about here}

All five papers were selected for inclusion in the CAT. While two studies had lower levels of evidence, they included a focus (on speech sound disorders) and setting (Australia) that 
were different to the other studies. It was felt to be important to include these perspectives in the CAT. This is supported by Noyes et al. (2018) who suggests that qualitative syntheses should include papers of lesser strength if they will potentially provide additional insights of relevance.

\section{Critical Appraisal of Current Best Available Evidence (APA Level 1):}

The Critical Appraisal Skills Program (CASP) Qualitative Checklist (2018; see Appendix A) was used by each CAT author independently to appraise the methodological quality of each paper. There was a high level of agreement about the quality ratings of all five papers, although each author raised some complementary but different issues in regard to various aspects of each paper.

Study 1: Davies et al. (2017) explored parent views of their roles in intervention, and how these views change throughout the therapy process. This study sampled parents of preschool children, from across the UK National Health Service (NHS), and used a parent reference group in the development of interview questions. The data collection process was very clearly explained, with incremental, purposive recruitment supporting iterative data collection and analysis, and saturation of data is discussed. An advisory board provided oversight, and this combined with the transparency of all aspects of data generation and analysis strengthened this study. This was a well conducted and reported study, representing moderate evidence for practice (level II of the Daly et al. 2007 hierarchy).

Study 2: Glogowska and Campbell (2000) is a seminal paper in this area, being the first to examine parent views of involvement in SLP services. The authors used purposive sampling, with the aim of achieving maximum variation in respondents. The study did not have clearly articulated aims but stated that it was "an investigation into parental views" of 
SLP (p. 392) and focused on parents of preschool children. The authors included a very clear justification of the methodology used and the interview guide is presented, clarifying what was discussed with parents. There is a robust description of analysis procedures and the role of the researcher in this study. This is a well conducted and reported study, representing level II qualitative evidence (moderate).

Study 3: James (2011) presented a qualitative synthesis, evaluating the use of the Normalisation Process Model (NPM) for explaining the embedding of SLP interventions in therapy practice. The author chose to evaluate the Hanen Parent Program (HPP) as the "embedded intervention". A secondary aim was to explore the insights provided by the synthesised qualitative studies using the NPM, to support a greater understanding of how the interactions between SLPs and parents support the embedding of this type of program in practice. This latter aim was judged to meet the PICo question for this CAT. The article reports a synthesis using a case study approach focusing on HPP. The strengths of the study include using NPM to map the findings of the synthesis, verification of this mapping by the authors of the NPM and by SLP colleagues, and a robust discussion of the new insights provided by this process. The author's relationship to NPM or to the HPP was unclear, and there were no clear examples of how the mapping of quotes and themes from the primary studies onto the NPM was undertaken. Hence there is potential bias in the interpretations presented. Overall, this study sits at level II of the Daly et al. (2007) hierarchy, presenting moderate evidence for practice.

Study 4: McAllister et al. (2011) presented two studies: a quantitative exploration of parent access to and use of SLP services (study A) and a qualitative examination of parent views about access to and involvement in SLP services (study B). Study B was reviewed for this CAP. There was robust description of data analysis processes, enhancing credibility of these findings. Parents were all of children aged 4-5 years with speech sound disorders; however it was unclear why the families who were interviewed were chosen, and there was limited 
discussion around data collection procedures, e.g., how the Speech Participation and Activity Assessment-Children (McLeod, 2004) was applied in interviews. This study presents indicative evidence, sitting at level III on the Daly et al. (2007) hierarchy.

Study 5: Watts Pappas et al. (2016) explored "parental beliefs and experiences regarding involvement in speech intervention for their preschool child with mild to moderate speech sound disorder" (p. 223) using qualitative interviews with parents. This study included iterative data collection and analysis, robust discussion of analysis, and presented clear clinical implications. It was unclear whether recruiting SLPS were from the same community health centre, and whether they approached families with certain backgrounds, experiences or characteristics to support purposive sampling. The interviewer was reported to be from "the same overall organization" (p. 227) as the SLPs recruiting children, but their exact relationship is unclear. However, the researcher kept a reflexive journal to support data analysis, which enhances the credibility of the study. Overall this study represents indicative evidence (level III).

Table 4 provides details about each study.

Insert table 4 about here

\section{CAT Findings (APA Level 1):}

\section{Individual Studies (APA Level 2):}

Study 1 (Davies et al., 2017) provides moderate evidence that parents of preschool-aged children view themselves as primarily advocates for their children, rather than interveners. Parents also see roles in SLP intervention at different levels: "attenders" (attending sessions but not getting involved), "implementers" (doing activities at home as provided or suggested by the SLP) or "adaptors" (changing their approach and being involved in "teaching" their child). The latter indicates active involvement that extends to changes in their overall 
interaction with their child. For example, Participant 1 explained that she learned to take a different approach to communication which was "More about having fun, if he's having fun he more happily talks" (p. 178). SLPs can potentially support parents toward a more active intervener role by capitalising on parents' expectation that they will learn and therefore coaching/teaching them "new ways" (Participant 1).

Study 2: Glogowska and Campbell (2000) provided moderate evidence that parents of preschoolers see three distinct phases to intervention: Getting in, Getting on, and Getting there. The first and final phases present uncertainty and even anxiety for parents. As explained by participant "Hayley" this was about facing the unknown: "I was a nervous wreck ... I, 'cos I didn't honestly know what to expect when I got there" (p. 398). These phases see parents take a more passive role in intervention and decision making, and they rely on the expert SLP to show them the right direction. "Patricia" illustrated this: "I don't make that decision [regarding discharge]...I don't really know what stage he's at" (p. 401). The Getting on phase (once intervention has commenced) has the most parent involvement, and parents may feel assured that something is being done. In this stage, parents expected SLPs to provide 'fresh' ideas for their child, versus "what you do with your kids anyway"; without this they may feel "what a waste of time" ("Dorothy"; p. 400). At all stages, incongruence between the therapy processes and parent expectations or needs were identified, leading to dissatisfaction with services.

Study 3: James' (2011) synthesis supported new insights into parent views of their involvement in the HPP intervention, at a moderate level of evidence. Parents showed flexibility in their conceptions of therapy, accepting over time that they are the targets of HPP intervention, versus their expectations that their children would be the focus. However, the analysis highlighted limited flexibility in parent conceptions of how intervention is directed: "for parents the authority and expertise remains with the speech and language therapists" ( $p$. 6), nor were conceptions of the outcomes desired from intervention flexible. Incongruity between professionals and parents with respect to outcomes limits parental satisfaction with 
intervention. The author postulates that collaboration between parents and therapists supports flexibility, but there is also a need for greater congruence in expectations.

Study 4: McAllister et al. (2011) provides indicative evidence that accessing and engaging with SLP services requires parents Being aware and Being able. In relation to this CAT, findings related to engaging with services are the focus. The authors identified that parents want to help their child, but potentially need guidance as to how to go about this. For example, "Zac's mother" indicated "I just tried to sit him down with something the other day, but I grabbed something too advanced" (p. 261). There is limited in-depth presentation of the findings around Being aware and it is not evident from this study how parents may want or need this awareness, nor how SLPs can support it. Being able is defined as parents having the capacity to engage, and this may be facilitated by children's readiness for intervention, the relationship with the SLP, and being able to fit intervention activities at home into their daily lives. The authors postulate that Being aware and Being able support positive, ongoing engagement with services, while lack of awareness or lack of capacity to engage lead to dissatisfaction and potentially disengagement with intervention.

Study 5: Watts Pappas et al. (2016) provides indicative evidence that parents want to "do the right thing by your kid" ("Kylie", p. 230). Seeking the expertise of the SLP is one way in which parents support their child, as noted by "Rebecca": "that's why you go to an expert, that's why I'm there, to get help" (p. 231). Parents also recognise that the SLP can't do everything, and expect to be involved with home practice, as Doug indicated "You can't expect him to do it once and then OK, I've learnt that" (p. 231). SLP interpersonal factors such as their engagement of the child, approachability, communication style were important to parental experiences of intervention. These authors identified that parents may hold back from involvement if they are unsure of their role or because they do not want to interfere, and overall may see themselves as a secondary partner, rather than a primary decision-maker with respect to intervention. 


\section{Synthesised Findings and Discussion (APA Level 2):}

The first author of this CAT undertook a thematic synthesis, examining the themes reported in each paper and looking for patterns, similarities and differences. This was checked by the second author. This synthesis discovered two major themes highlighted across these five studies: Parental Expectations and Flexibility.

Parental expectations. Parental expectations recurred as a theme across these studies, relating to the therapy process itself, the target of intervention (e.g., child versus parent focused), parent and therapist roles in intervention, and the outcomes of intervention. There was evidence that congruence between parental expectations and reality is an important factor in parental involvement. This starts at the initial contact with SLPS when parents' "expectations and preconceptions came face-to-face with the reality of attendance at the clinic" (Glogowska and Campbell, 2000, p. 398). This reality check may challenge specific expectations, e.g., that the SLP will "do" the intervention (Davies et al.,2017; Glogowska and Campbell, 2000; Watts Pappas et al., 2016), or that the intervention will be directed toward the child versus providing parents with training (James, 2011). Parental expectations may be vague or tentative (Davies et al.,2017; Glogowska and Campbell, 2000). This may mean there is more flexibility in these expectations (Davies et al.,2017), a concept discussed further below. On the other hand, even unclear or vaguely formulated expectations may be unmet or incongruent with reality, leading to dissatisfaction and potentially disengagement from services (Glogowska and Campbell, 2000; James, 2011; McAllister et al., 2011).

Parents expect to play a role as an advocate for their child (Davies et al.,2017; Watts Pappas et al., 2016). In seeking the expertise of the SLP, they are trying to do the best for their child. This explains why, for some parents, it is important for them that the SLP directly provide intervention while they take a more passive role (Watts Pappas et al., 2016). Parents don't necessarily expect or feel as confident in an "intervener" role and several studies 
highlighted that uncertainty about how they can help their child leads to parents "holding back" from involvement (Davies et al.,2017; Glogowska and Campbell, 2000; McAllister et al., 2011; Watts Pappas et al., 2016).

Across the reviewed studies in this CAT, it was clear that parental expectations about "involvement" did not always mean the same thing. Involvement was defined as something with multiple levels and modes, with Davies et al. (2017) providing conceptually different categories of parent involvement from "attenders" to "adaptors". Watts Pappas et al. (2016) provided evidence that while parents may be expecting to help their child by providing home practice, this does not necessarily mean they are willing to be involved in intervention sessions, nor in goal setting. Similarly Glogowska and Campbell, (2000) indicated that parents may anticipate some level of involvement, but that "being involved in their child's therapy and 'getting on' did not mean being left to 'get on with it"' (p. 402).

Parents bring expectations about SLPs, including that they will build relationships with both the child and the family (McAllister et al., 2011; Watts Pappas et al., 2016). They also expect SLPs to bring expertise to help their child. For example, Glogowska and Campbell (2000) indicated that parents rely on the SLP to evaluate their child's needs and outcomes and to provide direction for intervention and discharge, and this was echoed in Davies et al. (2017), James (2011), and Watts Pappas et al. (2016). Parents see multiple roles for SLPS, including as assessors, interveners, intervention planners, and teachers (Davies et al.,2017). The latter role indicates that parents expect SLPs to provide them with information and techniques to help their own child. Parents expect SLPs to have new, "fresh" knowledge or approaches to give them (Davies et al.,2017; Glogowska and Campbell, 2000) and they were prepared to take on new ways of working, if shown what to do (Davies et al.,2017; Glogowska and Campbell, 2000; McAllister et al., 2011; Watts Pappas et al., 2016).

Flexibility One of the insights arising from James (2011) was that parent expectations around intervention can be flexible. The author found that parents, who initially expected a child-directed focus, came to recognise the legitimacy of a parent-directed approach to 
intervention through their involvement in the HPP. The idea of flexibility was also evident in other studies in this CAT, notably Davies et al. (2017), which highlighted that parents' conceptions of their roles can change over the course of intervention, moving toward seeing themselves as interveners, rather than just advocates for their child. Watts Pappas et al., (2016) also suggested that parent expectations about involvement were dynamic, and that SLPs need to check in with families and "follow the families' lead" (p. 236) with respect to their desire for involvement. Glogowska and Campbell (2000) suggested that parental involvement in intervention was changeable, from passive during the Getting in phase, to more active during the Getting on phase, and back to passive in the Getting there phase.

There was evidence that SPS working collaboratively with parents promotes this flexibility (James, 2011; Watts Pappas et al., 2016) and that specific strategies, such as coaching/teaching parents about speech and language (Davies et al., 2017, Watts Pappas et al., 2016) and provision of appropriate resources to support involvement, such as home practice activities (McAllister et al., 2011; Watts Pappas et al., 2016) were important to support parents to change their expectations and involvement. Watts Pappas et al. (2016) highlighted the importance of SLPs providing explicit opportunities for parental involvement, giving parents openings to be more active if they wish to be. Parent expectations, discussed above, can be leveraged to support flexibility- for example, that SLPs will be teachers (Davies et al., 2017) and that the SLP has authority and expertise to provide advice for parents (James, 2011).

Flexibility may reach a ceiling as noted in Davies et al. (2017) and McAllister et al. (2011), where further coaching, support or resources cannot overcome the practical difficulties experienced by families in engaging directly with intervention. There may also be limited flexibility in relation some parental expectations, as James (2011) identified that parental expectations of therapy outcomes of the HPP did not change over time. Expected outcomes may present an area of anticipated anxiety or even conflict for parents (Glogowska and Campbell, 2000). A congruent understanding of where intervention is heading may reduce 
parental uncertainty and increase their involvement in the latter stages of intervention, and in decision-making around discharge.

These findings address the CAT question and promote a stronger understanding of parent views about their involvement in SLP intervention for preschool-aged children; recommendations are highlighted below.

\section{Recommendations for Practice/Policy (APA Level 2):}

These studies present indicative to moderate evidence (Daly, 2007) for practice in relation to involving parents of preschool-aged children in community-based SLP intervention. They suggest that:

- Parental expectations about their involvement in intervention needs to be directly clarified by SLPS, and this should include discussion of different modes and levels of involvement (e.g., doing home practice tasks, versus participation in sessions, versus decision-making).

- Parents view SLPS as both experts and teachers. They access SLP expertise to help their child, and expect SLPs to also teach them what they can to do for their child. Teaching parents about speech and language development and disorder, sharing expertise and providing fresh ideas and perspectives are important roles for SLPS which will support parental involvement.

- SLPs can also support parents to change their expectations and involvement by giving them appropriate resources and encouragement, and providing explicit opportunities such as shared decision-making. However, they should also be aware that factors such as family priorities and parental confidence may override this support, leading to less involvement than desired on both sides. 
- Parents' aspirations and capacity for involvement are not fixed. Thus, SLPs should provide an open, ongoing discussion about expectations and involvement, not a once-off conversation.

- An important area for establishing a common ground can be around the outcomes of interventions. A congruent understanding of expected outcomes may support higher involvement and satisfaction.

\section{Recommendations for Research (APA Level 2):}

The number of qualitative studies available in this area, particularly since 2011 , indicates a growing interest in research regarding engaging parents of preschool-aged children in SLP intervention. There are limitations to the existing research base, particularly with respect to the depth of findings reported, with findings currently sitting at indicative to moderate (level III to level II) evidence based on Daly et al (2007). There is scope for further research providing in-depth, interpretative explanatory understandings of parental involvement in SLP intervention and how SLPs can support this. Clarity around what is meant by involvement would be useful in future studies, with these studies highlighting that different levels of involvement may be viewed differently by parents, and potentially require different supports. 


\section{References}

Cooke, A., Smith, D., \& Booth, A. (2012). Beyond PICO: the SPIDER tool for qualitative evidence synthesis. Qualitative Health Research, 22(10), 1435-1443.

Critical Appraisal Skills Programme (2018). CASP Qualitative Checklist. [online] Available at: https://casp-uk.net/casp-tools-checklists/ Accessed: 10 $10^{\text {th }}$ April, 2018

Daly, J., Willis, K., Small, R., Green, J., Welch, N., Kealy, M., \& Hughes, E. (2007). A hierarchy of evidence for assessing qualitative health research. Journal of Clinical Epidemiology, 60(1), 43-49.

Davies, K. E., Marshall, J., Brown, L. J., \& Goldbart, J. (2017). Co-working: Parents' conception of roles in supporting their children's speech and language development. Child Language Teaching and Therapy, 33(2), 171-185.

Ebert, K. D. (2018). Parent perspectives on the clinician-client relationship in speechlanguage treatment for children. Journal of Communication Disorders, 73, 25-33.

Glogowska, M., \& Campbell, R. (2000). Investigating parental views of involvement in preschool speech and language therapy. International Journal of Language \& Communication Disorders, 35(3), 391-405.

James, D. M. (2011). The applicability of normalisation process theory to speech and language therapy: a review of qualitative research on a speech and language intervention. Implementation Science, 6(1), 95.

Kummerer, S. E., \& Lopez-Reyna, N. A. (2006). The role of Mexican immigrant mothers' beliefs on parental involvement in speech-language therapy. Communication Disorders Quarterly, 27(2), 83-94.

Marshall, J., Goldbart, J., \& Phillips, J. (2007). Parents' and speech and language therapists' explanatory models of language development, language delay and intervention. International Journal of Language \& Communication Disorders, 42(5), 533-555.

Marshall, J., Harding, S., \& Roulstone, S. (2017). Language development, delay and intervention — the views of parents from communities that speech and language 
therapy managers in England consider to be under-served. International Journal of Language \& Communication Disorders, 52(4), 489-500.

Mathisen, B., Bennett, S., Lockett, C., Beazley, K., Howlett, J., Charlesworth, M., . . Read, J. (2016). Talking Matters Bendigo: Engaging parents early to prevent long-term speech, language and communication needs in preschool-aged children. Children Australia, 41(4), 258-264.

McAllister, L., McCormack, J., McLeod, S., \& Harrison, L. J. (2011). Expectations and experiences of accessing and participating in services for childhood speech impairment. International Journal of Speech-Language Pathology, 13(3), 251-267.

McLeod, S. (2004). Speech pathologists' application of the ICF to children with speech impairment. Advances in Speech Language Pathology, 6(1), 75-81.

Noyes, J., Booth, A., Flemming, K., Garside, R., Harden, A., Lewin, S., . . Thomas, J. (2018). Cochrane Qualitative and Implementation Methods Group guidance paper 3: Methods for assessing methodological limitations, data extraction and synthesis, and confidence in synthesized findings. Journal of Clinical Epidemiology, 97, 49-58.

Sandelowski, M., \& Barroso, J. (2003). Classifying the findings in qualitative studies. Qualitative Health Research, 13(7), 905-923.

Watts Pappas, N., McAllister, L., \& McLeod, S. (2016). Parental beliefs and experiences regarding involvement in intervention for their child with speech sound disorder. Child Language Teaching and Therapy, 32(2), 223-239. 
Table 1: PICo elements derived from the focused clinical question.

\begin{tabular}{|l|l|}
\hline P & $\begin{array}{l}\text { Caregivers of children aged 2-5 years with speech, language or } \\
\text { other communication disorders }\end{array}$ \\
\hline I & $\begin{array}{l}\text { Views of their involvement in intervention } \\
\text { Alternative wording would include: opinions, perceptions, } \\
\text { attitudes, evaluations, experiences }\end{array}$ \\
\hline Co & $\begin{array}{l}\text { Speech-language pathology intervention in community-based } \\
\text { settings. The latter encompasses private practice and other } \\
\text { community settings such as community health, versus specialist } \\
\text { services (eg. hospital outpatient, early intervention, etc). }\end{array}$ \\
\hline
\end{tabular}


Table 2: Initial search terms for each database

\begin{tabular}{|c|c|c|}
\hline Databases Searched & Search Terms & Limits Used \\
\hline CINAHL & $\begin{array}{l}\text { TI (carer* or caregiver* or } \\
\text { "care giver" or parent* or } \\
\text { family* or families) OR } \\
\text { MESH: Caregivers OR } \\
\text { MESH: Parents } \\
\text { AND } \\
\text { TI or ABS (speech OR } \\
\text { language OR } \\
\text { communication OR } \\
\text { articulation OR stutter* OR } \\
\text { phonolog* OR fluency) AND } \\
\text { MESH: Speech-language } \\
\text { pathologists OR speech } \\
\text { therapy } \\
\text { AND } \\
\text { TI (view* or opinion* or } \\
\text { attitude* or evaluation* or } \\
\text { belief* or perception* or } \\
\text { OR MESH: Qualitative } \\
\text { studies }\end{array}$ & $\begin{array}{l}\text { Limit search to Preschool } \\
\text { child ( } 2 \text { to } 5 \text { years) }\end{array}$ \\
\hline
\end{tabular}




\begin{tabular}{|c|c|c|}
\hline ERIC & $\begin{array}{l}\text { TI or ABS (carer* or } \\
\text { caregiver* or "care giver" or } \\
\text { parent* or family or families) } \\
\text { AND } \\
\text { TI or ABS (speech OR } \\
\text { language OR } \\
\text { communication OR } \\
\text { articulation OR stutter* OR } \\
\text { phonolog* OR fluency) AND } \\
\text { Subject: speech-language } \\
\text { pathology } \\
\text { AND } \\
\text { TX qualitative OR TI (view* } \\
\text { OR opinion* OR attitude* } \\
\text { OR evaluation* OR belief* } \\
\text { OR attitude* OR } \\
\text { perception* OR } \\
\text { experience* }\end{array}$ & $\begin{array}{l}\text { Limit to Education Level: } \\
\text { Early Childhood Education, } \\
\text { Kindergarten, Preschool } \\
\text { Education }\end{array}$ \\
\hline
\end{tabular}




\begin{tabular}{|c|c|c|}
\hline SCOPUS & 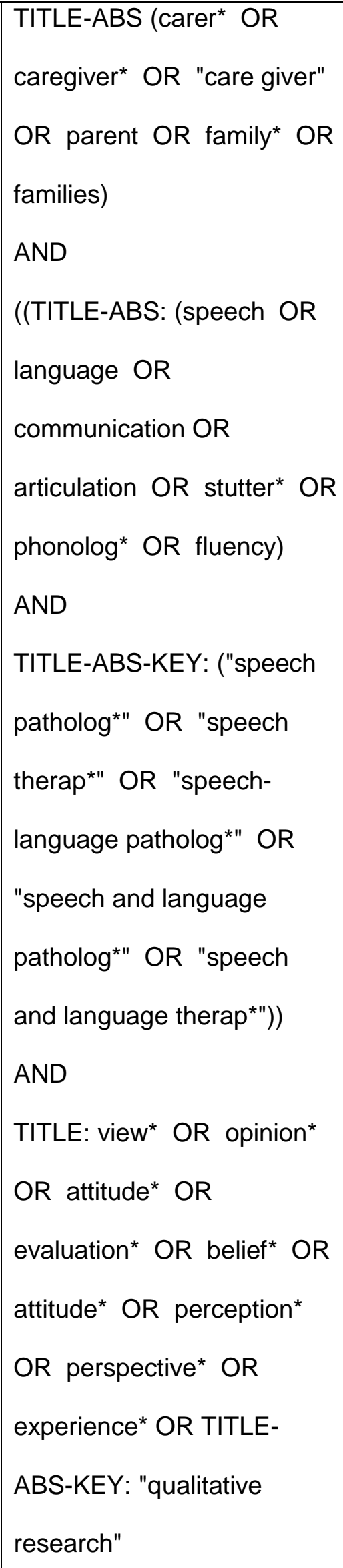 & None \\
\hline
\end{tabular}




\begin{tabular}{|l|l|l|}
\hline & AND & \\
AND TITLE-ABS-KEY: & \\
child* OR preschoo* ${ }^{*}$ OR & \\
kindergarten* & \\
\hline
\end{tabular}


Table 3: Papers chosen for this CAT and level of qualitative evidence

\begin{tabular}{|c|c|c|}
\hline $\begin{array}{l}\text { Study number, Author, Year \& Citation } \\
\text { details }\end{array}$ & $\begin{array}{l}\text { Design/Level of } \\
\text { qualitative findings } \\
\text { (Sandelowski and } \\
\text { Barroso, 2003) }\end{array}$ & $\begin{array}{l}\text { Level of } \\
\text { qualitative } \\
\text { evidence } \\
\text { (Daly et al., } \\
\text { 2007) }\end{array}$ \\
\hline $\begin{array}{l}\text { Study 1: Davies, K. E., Marshall, J., Brown, L. } \\
\text { J., \& Goldbart, J. (2017). Co-working: Parents' } \\
\text { conception of roles in supporting their children's } \\
\text { speech and language development. Child } \\
\text { Language Teaching and Therapy, 33(2), 171- } \\
185 .\end{array}$ & $\begin{array}{l}\text { Qualitative primary } \\
\text { research; } \\
\text { Conceptual/thematic } \\
\text { description }\end{array}$ & Level II \\
\hline $\begin{array}{l}\text { Study 2: Glogowska, M. \& Campbell, R. (2000). } \\
\text { Investigating parental views of involvement in } \\
\text { pre-school speech and language } \\
\text { therapy. International Journal of Language \& } \\
\text { Communication Disorders, 35(3), 391-405. }\end{array}$ & $\begin{array}{l}\text { Qualitative primary } \\
\text { research; } \\
\text { Conceptual/thematic } \\
\text { description }\end{array}$ & Level II \\
\hline $\begin{array}{l}\text { Study 3: James, D. M. (2011). The applicability } \\
\text { of normalisation process theory to speech and } \\
\text { language therapy: a review of qualitative } \\
\text { research on a speech and language } \\
\text { intervention. Implementation Science, } 6(1), 95 \text {. }\end{array}$ & $\begin{array}{l}\text { Qualitative synthesis; } \\
\text { Conceptual/thematic } \\
\text { description }\end{array}$ & Level II \\
\hline
\end{tabular}




\begin{tabular}{|l|l|l|}
\hline $\begin{array}{l}\text { Study 4: McAllister, L., McCormack, J., McLeod, } \\
\text { S., \& Harrison, L. J. (2011). Expectations and } \\
\text { experiences of accessing and participating in } \\
\text { services for childhood speech impairment. }\end{array}$ & research; Thematic \\
International Journal of Speech-Language & & \\
Pathology, 13(3), 251-267. & & \\
\hline $\begin{array}{l}\text { Study 5: Watts Pappas, N., McAllister, L., \& } \\
\text { McLeod, S. (2016). Parental beliefs and } \\
\text { experiences regarding involvement in } \\
\text { intervention for their child with speech sound } \\
\text { disorder. Child Language Teaching and }\end{array}$ & Qualitative primary & Level III \\
Therapy, 32(2), 223-239. & survey & \\
\hline
\end{tabular}


Table 4: Data Extraction and Characteristics of Included Studies

\begin{tabular}{|c|c|c|c|c|c|}
\hline & $\begin{array}{l}\text { Study } 1 \\
\text { Davies et al. (2017) }\end{array}$ & $\begin{array}{l}\text { Study } 2 \\
\text { Glogowska and } \\
\text { Campbell (2000) }\end{array}$ & $\begin{array}{l}\text { Study } 3 \\
\text { James (2011) }\end{array}$ & $\begin{array}{l}\text { Study } 4 \\
\text { McAllister et al. } \\
\text { (2011) }\end{array}$ & $\begin{array}{l}\text { Study } 5 \\
\text { Watts Pappas et al., } \\
\text { (2016) }\end{array}$ \\
\hline Population & $\begin{array}{l}\text { Parents of preschool } \\
\text { children ( } 2 \text { to } 5 ; 11) \\
\text { receiving treatment for } \\
\text { speech delay, } \\
\text { language delay or } \\
\text { dysfluency. }\end{array}$ & $\begin{array}{l}\text { Parents of preschool } \\
\text { children (< 4;6 years) } \\
\text { with speech and/or } \\
\text { language delay. }\end{array}$ & $\begin{array}{l}\text { Research studies that } \\
\text { explored parent } \\
\text { and/or therapist views } \\
\text { of the Hanen Parent } \\
\text { Program (HPP). }\end{array}$ & $\begin{array}{l}\text { Parents of children } \\
\text { (ages } 4 \text { to } 5 \text { ) with } \\
\text { primary speech sound } \\
\text { delays or disorders } \\
\text { (SSD). }\end{array}$ & $\begin{array}{l}\text { Parents of children } \\
(3 ; 0 \text { to } 5 ; 1) \text { with mild } \\
\text { to moderate SSD. }\end{array}$ \\
\hline $\begin{array}{l}\text { Sample and } \\
\text { sampling } \\
\text { design }\end{array}$ & $\begin{array}{l}\text { Fourteen parents } \\
\text { sampled purposively. } \\
\text { Iterative data } \\
\text { collection and } \\
\text { analysis, with } \\
\text { saturation of data } \\
\text { determined before }\end{array}$ & $\begin{array}{l}\text { Sixteen parents, } \\
\text { sampled purposively } \\
\text { for maximum } \\
\text { variation. Iterative } \\
\text { data collection and } \\
\text { analysis. }\end{array}$ & $\begin{array}{l}\text { Five papers, three of } \\
\text { which were qualitative } \\
\text { and two of which used } \\
\text { questionnaires, } \\
\text { chosen for their } \\
\text { examination of the } \\
\text { HPP. }\end{array}$ & $\begin{array}{l}\text { Thirteen parents. } \\
\text { Unclear sampling } \\
\text { methods. Sample was } \\
\text { varied in terms of } \\
\text { severity of SSD, } \\
\text { location and }\end{array}$ & $\begin{array}{l}\text { Seven parents (across } \\
\text { six families). Unclear } \\
\text { sampling methods. } \\
\text { Sampling was varied } \\
\text { in terms of severity of } \\
\text { SSD, work status and } \\
\text { experiences of }\end{array}$ \\
\hline
\end{tabular}




\begin{tabular}{|c|c|c|c|c|c|}
\hline & $\begin{array}{l}\text { ceasing data } \\
\text { collection. }\end{array}$ & & & $\begin{array}{l}\text { experiences of } \\
\text { intervention. }\end{array}$ & $\begin{array}{l}\text { intervention. Iterative } \\
\text { data collection and } \\
\text { analysis. }\end{array}$ \\
\hline Study Design & $\begin{array}{l}\text { Qualitative study } \\
\text { using semi-structured } \\
\text { interviews. }\end{array}$ & $\begin{array}{l}\text { Qualitative study } \\
\text { using semi-structured } \\
\text { interviews. }\end{array}$ & $\begin{array}{l}\text { Qualitative synthesis, } \\
\text { using a "case study" } \\
\text { approach. }\end{array}$ & $\begin{array}{l}\text { Qualitative study } \\
\text { using semi-structured } \\
\text { interviews. }\end{array}$ & $\begin{array}{l}\text { Qualitative study } \\
\text { using semi-structured } \\
\text { interviews }\end{array}$ \\
\hline $\begin{array}{l}\text { Study Aim and } \\
\text { phenomena of } \\
\text { interest }\end{array}$ & $\begin{array}{l}\text { Parents' conceptions } \\
\text { of roles in SLP, and } \\
\text { how these roles } \\
\text { change during the } \\
\text { intervention process. }\end{array}$ & $\begin{array}{l}\text { Parent perceptions of } \\
\text { SLP and the process } \\
\text { of involvement in SLP. }\end{array}$ & $\begin{array}{l}\text { How the professional- } \\
\text { parent relationship } \\
\text { supports the } \\
\text { embedding of } \\
\text { interventions into } \\
\text { practice. }\end{array}$ & $\begin{array}{l}\text { Parent views of } \\
\text { seeking and engaging } \\
\text { with SLP services. }\end{array}$ & $\begin{array}{l}\text { Parent beliefs, } \\
\text { experiences and } \\
\text { choices in relation to } \\
\text { involvement in SLP. }\end{array}$ \\
\hline $\begin{array}{l}\text { Context from } \\
\text { which } \\
\text { participants } \\
\text { were recruited }\end{array}$ & $\begin{array}{l}\text { Public preschool SLP } \\
\text { services, across four } \\
\text { NHS sites, UK. }\end{array}$ & $\begin{array}{l}\text { RCT run in a } \\
\text { community SLP } \\
\text { service in Bristol, } \\
\text { England. }\end{array}$ & NA & $\begin{array}{l}\text { Sound Effects study, } \\
\text { recruited from } 33 \text { early } \\
\text { childhood centres in } \\
\text { NSW and Victoria, } \\
\text { Australia. }\end{array}$ & $\begin{array}{l}\text { Public preschool SLP } \\
\text { services in } \\
\text { Queensland, Australia }\end{array}$ \\
\hline
\end{tabular}




\begin{tabular}{|c|c|c|c|c|c|}
\hline Methodology & $\begin{array}{l}\text { Parents interviewed } \\
\text { up to three times in } 30 \\
\text { weeks. Data analysis } \\
\text { applied Thematic } \\
\text { Networks Analysis, } \\
\text { and Framework } \\
\text { Analysis within the } \\
\text { overall theoretical } \\
\text { framework of } \\
\text { "Conceptual change } \\
\text { theory" }\end{array}$ & $\begin{array}{l}\text { Parents interviewed } \\
\text { once. Framework } \\
\text { Analysis was used for } \\
\text { data analysis. }\end{array}$ & $\begin{array}{l}\text { The recurrent themes } \\
\text { and published quotes } \\
\text { within the primary } \\
\text { papers were mapped } \\
\text { against the constructs } \\
\text { of the NPM and new } \\
\text { insights were drawn } \\
\text { from this. }\end{array}$ & $\begin{array}{l}\text { Parents were } \\
\text { interviewed up to two } \\
\text { times. Thematic } \\
\text { analysis was used } \\
\text { within a } \\
\text { phenomenological } \\
\text { theoretical approach. }\end{array}$ & $\begin{array}{l}\text { Parents were } \\
\text { interviewed three } \\
\text { times- prior to, during } \\
\text { and post intervention. } \\
\text { Data analysis drew on } \\
\text { Thematic Networks } \\
\text { Analysis and } \\
\text { Framework Analysis } \\
\text { within an Interpretivist } \\
\text { theoretical framework. }\end{array}$ \\
\hline $\begin{array}{l}\text { Study } \\
\text { Limitations }\end{array}$ & $\begin{array}{l}\text { Negative cases not } \\
\text { included (e.g., parents } \\
\text { not opting for SLP } \\
\text { services). }\end{array}$ & $\begin{array}{l}\text { Parents were } \\
\text { participants in an RCT } \\
\text { from one service only. }\end{array}$ & $\begin{array}{l}\text { Only studies relating } \\
\text { to HPP were } \\
\text { analysed. }\end{array}$ & $\begin{array}{l}\text { Sampling and data } \\
\text { collection were } \\
\text { unclear. Limited } \\
\text { discussion about } \\
\text { involvement of }\end{array}$ & $\begin{array}{l}\text { Sampling was } \\
\text { unclear. Unclear use } \\
\text { of longitudinal } \\
\text { element- ie changes } \\
\text { in views over time. }\end{array}$ \\
\hline
\end{tabular}




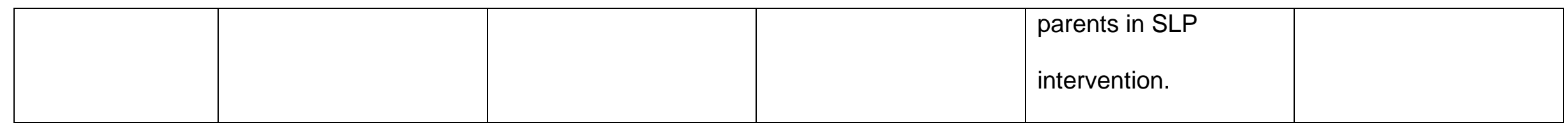




\section{Appendix A: Critical Appraisals}

\section{Critical Appraisal Skills Program (CASP) Checklist}

Reviewer: Jemma Skeat (JS) and Hazel Roddam (HR) Date: 15 June, 2018

Article: Davies et al. (2017)

\begin{tabular}{|c|c|c|}
\hline & JS & HR \\
\hline 1. Was there a clear statement of the aims of the research? & Yes & Yes \\
\hline 2. Is a qualitative methodology appropriate? & Yes & Yes \\
\hline $\begin{array}{l}\text { 3. Was the research design appropriate to address the aims of the } \\
\text { research? }\end{array}$ & Yes & Yes \\
\hline $\begin{array}{l}\text { 4. Was the recruitment strategy appropriate to the aims of the } \\
\text { research? }\end{array}$ & Yes & Yes \\
\hline 5. Was the data collected in a way that addressed the research issue? & Yes & Yes \\
\hline $\begin{array}{l}\text { 6. Has the relationship between researcher and participants been } \\
\text { adequately considered? }\end{array}$ & Yes & Yes \\
\hline 7. Have ethical issues been taken into consideration? & Yes & Yes \\
\hline 8. Was the data analysis sufficiently rigorous? & Yes & Yes \\
\hline 9. Is there a clear statement of findings? & Yes & Yes \\
\hline \multirow{3}{*}{\multicolumn{3}{|c|}{$\begin{array}{l}\text { 10. How valuable is the research? (Comments only) } \\
\text { JS: Clinical implications are considered and clearly outlined. } \\
\text { HR: The paper very clearly articulates the key take-home messages regarding implications for } \\
\text { practitioners working with parents of young children. The potential application of these } \\
\text { findings in practice is also clearly stated, including a coherent justification for the significance } \\
\text { of this as service delivery increasingly incorporates a parent education role. }\end{array}$}} \\
\hline & & \\
\hline & & \\
\hline Overall appraisal: & Include & Include \\
\hline
\end{tabular}




\section{Critical Appraisal Skills Program (CASP) Checklist}

Reviewer: Jemma Skeat (JS) and Hazel Roddam (HR) Date: 26 June 2018

Article: Glogowska and Campbell (2000)

\begin{tabular}{|c|c|c|}
\hline & JS & HR \\
\hline $\begin{array}{l}\text { 1. Was there a clear statement of the aims of the research? } \\
\text { JS: The background/intro justifies the need and overall goal, however } \\
\text { there are not overtly specified research aims. }\end{array}$ & Can't tell & Yes \\
\hline 2. Is a qualitative methodology appropriate? & Yes & Yes \\
\hline $\begin{array}{l}\text { 3. Was the research design appropriate to address the aims of the } \\
\text { research? }\end{array}$ & Yes & Yes \\
\hline $\begin{array}{l}\text { 4. Was the recruitment strategy appropriate to the aims of the } \\
\text { research? }\end{array}$ & Yes & Yes \\
\hline 5. Was the data collected in a way that addressed the research issue? & Yes & Yes \\
\hline $\begin{array}{l}\text { 6. Has the relationship between researcher and participants been } \\
\text { adequately considered? }\end{array}$ & Yes & Yes \\
\hline 7. Have ethical issues been taken into consideration? & Yes & Yes \\
\hline 8. Was the data analysis sufficiently rigorous? & Yes & Yes \\
\hline 9. Is there a clear statement of findings? & Yes & Yes \\
\hline \multicolumn{3}{|c|}{$\begin{array}{l}\text { 10. How valuable is the research? (Comments only) } \\
\text { JS: Clinical applications are discussed clearly and the findings are related to the literature. } \\
\text { HR: The paper clearly articulates the key take-home messages of implications for services. In } \\
\text { addition, it makes the case for the value of exploratory (qualitative) research designs for } \\
\text { gaining insights into parents' values and beliefs about access to services. }\end{array}$} \\
\hline Overall appraisal: & Include & Include \\
\hline
\end{tabular}


Critical Appraisal Skills Program (CASP) Checklist

Reviewer: Jemma Skeat (JS) and Hazel Roddam (HR)

Date: 26 June, 2018

Article: James (2011)

\begin{tabular}{|c|c|c|}
\hline & JS & HR \\
\hline 1. Was there a clear statement of the aims of the research? & Yes & Yes \\
\hline 2. Is a qualitative methodology appropriate? & Yes & Yes \\
\hline $\begin{array}{l}\text { 3. Was the research design appropriate to address the aims of the } \\
\text { research? }\end{array}$ & Yes & Yes \\
\hline $\begin{array}{l}\text { 4. Was the recruitment strategy appropriate to the aims of the } \\
\text { research? }\end{array}$ & Yes & Yes \\
\hline 5. Was the data collected in a way that addressed the research issue? & Yes & Yes \\
\hline $\begin{array}{l}\text { 6. Has the relationship between researcher and participants been } \\
\text { adequately considered? } \\
\text { JS: It is unclear this researcher's relationship to the Normalisation } \\
\text { Process Theory being examined, or to Hanen or the studies included, } \\
\text { or their personal interaction with the data. }\end{array}$ & Can't tell & Yes \\
\hline 7. Have ethical issues been taken into consideration? & Yes & Yes \\
\hline 8. Was the data analysis sufficiently rigorous? & Yes & Yes \\
\hline 9. Is there a clear statement of findings? & Yes & Yes \\
\hline \multicolumn{3}{|c|}{$\begin{array}{l}\text { 10. How valuable is the research? (Comments only) } \\
\text { JS: There are limitations around the application of Normalisation Process Theory (NPT) as } \\
\text { this review indicates that the model does not fully explain why Hanen Parent Program is } \\
\text { successful, given that it would predict that SLPs are experts at helping parents change their } \\
\text { views around their role in SLP. This was not found to be the case, yet HPP is well used. } \\
\text { HR: This paper highlights the potential value of a pursuing a greater range of qualitative } \\
\text { research designs to better understand these aspects of SLP practice. However, the case for } \\
\text { the utility of using the NPT model is equivocal. }\end{array}$} \\
\hline Overall appraisal: & Include & Include \\
\hline
\end{tabular}




\section{Critical Appraisal Skills Program (CASP) Checklist}

Reviewer: Jemma Skeat (JS) and Hazel Roddam (HR) Date: 26 June 2018

Article: McAllister et al (2011)

\begin{tabular}{|c|c|c|}
\hline & JS & HR \\
\hline 1. Was there a clear statement of the aims of the research? & Yes & Yes \\
\hline 2. Is a qualitative methodology appropriate? & Yes & Yes \\
\hline $\begin{array}{l}\text { 3. Was the research design appropriate to address the aims of the } \\
\text { research? }\end{array}$ & Yes & Yes \\
\hline $\begin{array}{l}\text { 4. Was the recruitment strategy appropriate to the aims of the } \\
\text { research? } \\
\text { Both reviewers noted that while a broad spectrum of characteristics } \\
\text { (including severity of speech problems, rurality, and access to and } \\
\text { experience of services) was accounted for in the sample, it is not clear } \\
\text { the relationship between these characteristics and the sampling } \\
\text { strategy, nor how participants were recruited. }\end{array}$ & Can't tell & Can't tell \\
\hline $\begin{array}{l}\text { 5. Was the data collected in a way that addressed the research issue? } \\
\text { Both reviewers noted that the topic guide is not presented and the } \\
\text { authors state that specific frameworks (eg Speech Participation and } \\
\text { Activity Assessment-Children (McLeod, 2004) were used to guide } \\
\text { questions, but it is not clear how. }\end{array}$ & No & Can't tell \\
\hline $\begin{array}{l}\text { 6. Has the relationship between researcher and participants been } \\
\text { adequately considered? }\end{array}$ & Can't tell & Yes \\
\hline JS: It is unclear the researcher's relationship to the parents involved. & & \\
\hline $\begin{array}{l}\text { 7. Have ethical issues been taken into consideration? } \\
\text { Both reviewers noted that information relevant to ethical issues was not } \\
\text { clearly stated in this paper. }\end{array}$ & Can't tell & Can't tell \\
\hline 8. Was the data analysis sufficiently rigorous? & Yes & Yes \\
\hline 9. Is there a clear statement of findings? & Yes & Yes \\
\hline \multicolumn{3}{|l|}{ 10. How valuable is the research? (Comments only) } \\
\hline
\end{tabular}


JS: The qualitative study helped to illuminate the findings of another study presented first in this paper. The authors present a model that indicates that parents are 'more likely' to disengage from services when not aware and not able to participate. However, there is limited discussion about what participation means, and how this may be assisted. Additionally, only one small section deals with parents 'being aware' of involvement in SLP services.

HR: The paper clearly articulates the key take-home messages, especially regarding parents' values and beliefs about access to services. The implications of these findings for working across demographics are very important, especially for hard-to-reach populations.

Overall appraisal: \begin{tabular}{|l|l|} 
Include & Include
\end{tabular}

\section{Critical Appraisal Skills Program (CASP) Checklist}

Reviewer: Jemma Skeat (JS) and Hazel Roddam (HR) Date: 26 June 2018

Article: Watts Pappas et al (2016)

\begin{tabular}{|l|l|l|}
\hline & JS & HR \\
\hline 1. Was there a clear statement of the aims of the research? & Yes & Yes \\
\hline $\begin{array}{l}\text { 2. Is a qualitative methodology appropriate? } \\
\text { 3. Was the research design appropriate to address the aims of the } \\
\text { research? }\end{array}$ & Yes & Yes \\
\hline $\begin{array}{l}\text { 4. Was the recruitment strategy appropriate to the aims of the } \\
\text { research? } \\
\text { JS: The relationship of the recruiting SLPs to the interviewer/ } \\
\text { researcher is unclear, as they are said to work at the same overall } \\
\text { organisation. }\end{array}$ & Can't tell & Yes \\
\hline $\begin{array}{l}\text { 5. Was the data collected in a way that addressed the research issue? } \\
\text { 6. Has the relationship between researcher and participants been } \\
\text { adequately considered? }\end{array}$ & Yes & Yes \\
\hline $\begin{array}{l}\text { 7. Have ethical issues been taken into consideration? } \\
\text { 8. Was the data analysis sufficiently rigorous? }\end{array}$ & Yes \\
\hline
\end{tabular}


9. Is there a clear statement of findings?

Yes

Yes

10. How valuable is the research? (Comments only)

JS: The paper links the findings to the research aims, with discussion of clinical implications.

HR: The paper clearly presents how the findings have contributed towards answering the original four research objectives. The clinical implications of the findings are very clearly highlighted.

Overall appraisal: Include $\quad$ Include 